\title{
12. The new normal, or the same old? The experiences of domestic workers in Singapore
}

Laura Antona

While extensive and far-reaching, the COVID-r9 pandemic did not impact all nations - or all people - equally. Within Singapore, a country that was lauded, at least initially, for its exemplary approach to controlling the pandemic (Teo 2020), the ways in which the virus ultimately spread through the city-state exposed existing inequalities and injustices in its migrant worker populations, with construction workers' dormitories becoming the epicentre of the nation's outbreaks.

This chapter engages directly with these injustices to demonstrate how migrant domestic workers were impacted by the global pandemic, particularly by the 'circuit-breaker' measures enforced by the Singaporean state. ${ }^{\mathrm{I}}$ As such, it argues three core points. First, that many domestic workers were subjected to increased surveillance and bodily control during the COVID-I9 pandemic, with the home space becoming the centre of this. Second, that many migrant workers experienced a removal of their rights and increased immobility. Finally, this chapter argues that, for many domestic workers, there was very little change to their circumstances, with the notion of the 'new normal' requiring further interrogation. Indeed, this chapter ultimately suggests that the experiences of populations who ordinarily experience prolonged confinement need further consideration if we are to achieve more just and equitable futures for all post-COVID-I9.

Significantly, this chapter was written while I was living under restrictions in the UK during the COVID-I9 pandemic. As such, the interviews and informal conversations on which it is based were conducted online with domestic workers, activists, and NGO workers/volunteers with whom I had existing relationships following prolonged ethnographic fieldwork between June 2016 and December 2017. Knowing

How to cite this book chapter:

Antona, Laura. 2022. 'The new normal, or the same old? The experiences of domestic workers in Singapore'. In: Shin, Hyun Bang; Mckenzie, Murray; and Oh, Do Young (eds) COVID-I9 in Southeast Asia: Insights for a post-pandemic world. London: LSE Press, pp. I4I-I49. DOI: https://doi.org/I0.3 I389/lsepress.cov.l License: CC BY 4.०. 
about these individuals' lives and perspectives prior to the outbreak of the global pandemic, I build on this more recent dialogue and use this chapter to detail how, and in some cases if, the COVID-I9 pandemic impacted the domestic worker population of Singapore. All of the names included in this chapter are pseudonyms.

\section{Increased bodily surveillance and tensions in the home}

Unlike labour that takes place in more public settings, both the intimacy and spatiality of domestic labour mark it as distinct, often leaving domestic workers under heightened scrutiny from their employers. This is particularly acute for live-in domestic workers, who not only have to work and rest in the home of their employer but are often overworked and experience increased vulnerability to abuse (Anderson 2000; Constable 1997; Ehrenreich and Hochschild 2002; Huang and Yeoh 2007; Parreñas 200I). In Singapore, as in many other national contexts, domestic workers are only able to migrate under an employer-sponsored scheme, rendering employers responsible for workers' salaries, accommodation, food, and well-being (MOM 202I). In addition to their bodily maintenance, employers are also made to be responsible for domestic workers' bodily control, with it being argued that the state legislates this in such a way as to leave them vulnerable to intense surveillance (Chok 20I3; MOM 202I). While conducting ethnographic fieldwork prior to the COVID-I9 pandemic, I encountered many domestic workers who had either been monitored by CCTV or watched closely by family members to ensure that they did not rest and worked to the standard required by their employers (Antona 20I9). This often became a point of tension and distress.

While many domestic workers are used to a high degree of surveillance, the pandemic further intensified this. Indeed, following the introduction of circuit-breaker measures, one of the key changes addressed by the domestic workers I interviewed was the sustained presence of their employer (and employer's family) in the home. One domestic worker, Benilda, said very simply in an exasperated tone: 'It just means I am being watched all the time.' She explained that, because she did not have a bedroom of her own, instead sleeping on the floor of her employer's child's room, she had no privacy or space to rest. While she would ordinarily have the house to herself on weekdays, meaning she could sit at the table to relax or could call her children at convenient times, she explained that she felt unable to do this in front 
of her employer and so would not sit down all day. She also added that she would make smaller portions of food for herself, fearful that her employer would think she was taking too much.

These sentiments were shared by many others, who also expressed their frustrations with having less rest and an increased workload. Rose, another domestic worker I interviewed, said that the amount of cleaning and cooking increased dramatically, especially as the family was no longer eating any meals out. She explained: 'They always eating, the children playing, making mess, I get so tired from all the work.' Rose also said that she would be able to cope more easily if she was not constantly being watched and could take some time off: 'It's more pressure to be watched as well.'

In addition to the increased bodily surveillance and workload, and perhaps as a result of this, many domestic workers also described heightened tensions in the home. As mentioned, both the intensive bodily surveillance enacted by many employers and the intimacy of domestic labour often produce friction between employer and employee, with domestic workers remaining highly vulnerable to mistreatment, abuse, and being overworked. During the pandemic, activists, NGOs, politicians, advocates, and survivors across the world spoke out about the increase in domestic violence and abuse (Bradbury-Jones and Isham 2020; End Violence Against Children 2020; Women's Aid 2020). Indeed, it has been widely shown that increased societal and household stress whether it be produced socially, economically, politically, or otherwise - often results in higher rates of domestic violence (Aoláin, Haynes, and Cahn 20II; Bradley 20I8; Tyner 20I2). While none of the domestic workers that I spoke to said that they had experienced any physical violence during this period, many attested to increased working hours and more stressful living/working environments. In addition, HOME (the Humanitarian Organization for Migration Economics), an NGO that supports domestic workers in Singapore and operates a helpline, verified a $25 \%$ increase in calls after the government introduced circuit-breaker measures (The Star 2020). FAST (the Foreign Domestic Worker Association for Social Support and Training), another NGO that supports domestic workers in Singapore, also reported increased tensions within home spaces, suggesting that the number of domestic workers fleeing their employers' homes had doubled in the months of March and April 2020 (Yang 2020).

It is evident, then, that in many circumstances an employer's continued presence in the home caused increased tensions during the 
pandemic. With more domestic workers seeking support from NGOs and their embassies and in some circumstances fleeing their employer's homes, it is clear that the circuit-breaker measures detrimentally impacted the working and living conditions in the home space for many of these labourers. While Rose's and Benilda's increased discomfort and hardship were, thankfully, short-lived - as their employers returned to work (and their employers' children to school) following the relaxation of the circuit-breaker measures in June 2020 - many other homes were permanently impacted, causing domestic workers to flee these spaces and return to their 'home' nations.

\section{Removal of rights and decreased mobility}

While often defined by their mobile status, many migrant labourers, including domestic workers, were rendered immobile by the COVID-I9 pandemic in many respects. Indeed, the pandemic enforced stillness at multiple scales: within national borders, within urban regions, and within the micro scale of the home. In Singapore, particularly when the circuit-breaker measures were in place, many domestic workers were unable to travel to and from their home countries. One domestic worker, Maya, had been hoping to travel to Indonesia to visit her children during the summer of 2020 , having not seen them for four years, prior to renewing her employment contract. She explained how upset she was at deciding not to travel back, instead renewing her contract and delaying a visit for another two years. Maya explained that she felt she had no choice in her decision, as she could not risk getting stuck in Indonesia; her wages were vital for providing her children with education.

Beyond being confined within the national borders of Singapore, many domestic workers also discussed the tightened societal controls and their enforced confinement to their employer's home. Indeed, domestic workers were encouraged not to leave their employers' homes on their weekly day off, requiring them to rest in their place of work. ${ }^{2}$ Margielyn was just one domestic worker who expressed her upset with this, explaining: 'Even if I can't meet with friends, staying in all day always means more work.' Like others, Margielyn said she understood the need for the circuit-breaker measures but felt unable to get any rest without a room of her own. Being bound to the home in the presence of her employer meant that she would be asked to do small 'favours' or jobs regularly, ultimately requiring her to work every day. While being restricted to the home space was a shared experience of Singaporean 
citizens and migrants alike, the lack of freedom to move around the city also resulted in a removal of many domestic workers' rights to rest and time off from work. Even after the circuit-breaker measures were lifted, Margielyn explained that her employer would not allow her outside on her day off. She stated: 'Ma'am thinks I will meet with friends and bring back the virus, so she don't allow me out.' The lack of trust within this relationship, paired with her employer's unequal positioning of power and the bodily controls that they were able to exert, meant that Margielyn, like many other domestic workers who would ordinarily be given a weekly rest day, continued to be subjected to confinement long after Singaporean citizens were allowed more freedom and mobility.

Alongside these experiences of heightened immobility, some domestic workers were, conversely, forced to move out of Singapore. During the circuit-breaker period, the Singaporean state affirmed that it would carry out inspections of key sites to ensure that migrant labourers did not break any social distancing measures (Zhuo 2020). If caught doing so, the state did not, however, impose the same punishment as it did to citizens. Instead of being fined, migrant workers were liable to have their work passes revoked and be blacklisted, meaning they would be unable to work in Singapore again (Zhuo 2020). A volunteer from HOME suggested that the population's unease, or perhaps disdain, towards migrants might have impacted the state's decision to further stratify the rights and positioning of citizens vis-à-vis non-citizens. Interestingly, this rule was applied not only to domestic workers and other foreign workers in Singapore but also to White 'expats', or 'professionals', who did not adhere to circuit-breaker regulations (Low 2020).

It can, therefore, be argued that the COVID-I9 pandemic resulted, even if temporarily, in a reconfiguring of both mobility and migration within Singapore and Southeast Asia more broadly. Rather than leaving Singapore for a holiday or ending a period of employment and feeling certain that returning for new work would be simple, domestic workers had to make decisions on whether to remain in the city-state for a prolonged period or to return to their 'home' countries with no certainty that they could return when desired. This decision, for Maya and others, proved particularly distressing. Indeed, while domestic workers' ability to move to and from Singapore was always mediated by the state and their ability to freely move around the city was always controlled by their employers, the additional circuit-breaker measures further decreased their mobility and freedoms, leading to an increased workload and a restriction of their rights. 


\section{The new normal or the same old?}

Alongside the aforementioned concerns, several domestic workers, interestingly, reported that they had experienced no significant changes to their lives in Singapore since the global pandemic had begun. In interviews, comments such as 'no sister, nothing change' and 'things are quite OK, the same really' led me to question how this could be the case when so much attention had been on how quickly and greatly the world had transformed. While none of these domestic workers were entirely happy in their employment, their working environments had not deteriorated or worsened during this period. In interviews, it transpired that none of these women had been given a day off prior to the circuit-breaker measures, when their employers would have regularly been at home. As such, their already heavily restricted mobility, the dynamic/relationships within the home and the surveillance they were under were not impacted.

While discourse during the pandemic largely focused on the ways in which labour practices and people's relationships with space changed both profoundly and quickly, it was striking that these domestic workers' experiences had remained unaffected. Upon reflection, however, it became clear that it was an individual's prior experience of freedoms that made their enforced confinement so starkly felt. For many domestic workers, being forced to live and work in the same space, confined to the same few rooms for months or even years, is the norm and an employment decision that they make because the financial opportunities and gains are so much more significant than any other options they have.

\section{Conclusion}

When considering the impacts of the COVID-I9 pandemic on the daily lives of domestic workers in Singapore, and particularly when reflecting on comments and sentiments about a lack of change to some individuals' lives, it is clear that their situation was unique. While it became evident through interviews that the imposed circuit-breaker measures had heightened certain tensions in the home spaces in which domestic workers lived and worked, the issues described were not entirely new. Indeed, domestic workers that I interviewed through the course of my extended ethnographic fieldwork for my $\mathrm{PhD}$ thesis commented widely on their level of surveillance and a relentless workload, as well as a lack of free time, rest, and basic rights. Rather than being a 'new normal', 
then, it became evident that, for most domestic workers, the issues that arose during the pandemic were, in fact, more of the 'same old'.

While it is important for policymakers, activists, NGOs and others to recognise the increased surveillance and household tensions that domestic workers were subjected to, as well as their more limited rights and mobility, it is also important to re-examine the structures and systems in place within Singapore that have maintained this form of labour migration. With increased concern about both the immediate and longer-term physical and mental health consequences of enforced confinement (as there has been globally with lockdowns and circuit-breaker measures), it is important to reflect on those individuals whose daily lives are ordinarily heavily confined. Live-in domestic workers, particularly those with minimal or no days of rest, regularly experience isolation and confinement for extended periods, sometimes years. When taking into account a domestic worker's inability to choose when and what they eat, the physically and emotionally arduous labour that they perform without rest, the social isolation they are forced to endure (particularly for those people who are not allowed to use their mobile phones and can only speak to their family and friends at limited times), and their precarious status, which renders them dependent upon their employer, it is clear that their mental and physical well-being should be a much more significant societal priority. Rather than remaining concerned only by the changes that the COVID-I9 pandemic and lockdowns/circuit-breakers brought to Southeast Asia and the world at large, it is also important to reflect on those whose daily lives were not altered during this period. Only then might we be able to work towards a more equitable future for all.

\section{Notes}

I. Similar to 'lockdown' measures in many other countries around the globe, circuit-breaker measures were introduced in Singapore on 7 April 2020, by the state, in order to control the spread of COVID-I9. This period saw the closure of schools, workplaces and non-essential shops, as well as mandated social distancing/isolation, in order to minimise the spread of the virus.

2. While the Employment of Foreign Manpower Act (MOM 202I) states that domestic workers in Singapore are entitled to one weekly day off and 'adequate' daily rest, this ruling was ultimately not enshrined in law and can be circumvented if there is written agreement by the employee and employer. 


\section{Acknowledgements}

My foremost thanks go to the migrant domestic workers who informed this writing and who continue to graciously give up their free time to talk to me about their ongoing experiences. I would also like to give particular thanks to Hyun Bang Shin, who, as my former PhD supervisor, continues to support my work and provide me with mentorship. Finally, I would like to thank Do Young Oh, Murray Mckenzie and the other editors from the LSE Press, for their suggested revisions and support in the production of this chapter.

\section{References}

Anderson, Bridget. (2000). Doing the Dirty Work? The Global Politics of Domestic Labour. USA: Zed Books.

Antona, Laura. (2019). 'Making hidden spaces visible: Using drawing as a method to illuminate new geographies'. Area, vol. 5 I, no. 4, pp. 697-705. https://doi.org/IO.I I I I/area.I 2526

Aoláin, Fionnuala Ní; Haynes, Dina Francesca; and Cahn, Naomi. (20I I). On the Frontlines. Gender, War, and the Post-Conflict Process. UK: Open University Press.

Bradbury-Jones, Caroline; and Isham, Louise. (2020). 'The pandemic paradox: The consequences of COVID-I9 on domestic violence'. Journal of Clinical Nursing, vol. 29, no. I3-I 4, pp. 2047-2049. https://doi.org/IO. I I I I/jocn . I 5296

Bradley, Samantha. (2018). 'Domestic and family violence in post-conflict communities. International human rights law and the state's obligation to protect women and children'. Health and Human Rights Journal, vol. 20, no. 2, pp. I 23-I36. https://perma.cc/UA 3 U-E $45 \mathrm{X}$ [Last accessed 23 May 202I].

Chok, Stephanie. (2013). Labour Justice and Political Responsibility: An Ethics-Centred Approach to Temporary Low-Paid Labour Migration in Singapore. Unpublished thesis (PhD), Murdoch University.

Constable, Nicole. (I 997). Maid to Order in Hong Kong. Stories of Migrant Workers. USA: Cornell University Press.

Ehrenreich, Barbara; and Hochschild, Arlie Russell. (2002). Global Woman: Nannies, Maids and Sex Workers in the New Economy. UK: Granta Publications.

End Violence Against Children. (2020). Protecting Children During COVID-I 9. Campaign webpage. https://perma.cc/FP $7 \mathrm{R}-4 \mathrm{~B}_{53}$ [Last accessed 2I April 2O2I]. 
Huang, Shirlena; and Yeoh, Brenda S.A. (2007). 'Emotional labour and transnational domestic work: The moving geographies of "maid abuse" in Singapore'. Mobilities, vol. 2, no. 2, pp. I95-2I7.

Low, Dominic. (2020). 'Robertson Quay incident: Seven fined, work passes for six revoked'. Straits Times, 26 June. https://perma.cc/6YUX-FXZT [Last accessed 2I April 202I].

MOM (Ministry of Manpower). (202I). Employment of Foreign Manpower Act (Chapter 9гA). Employment of Foreign Manpower (Work Passes) Regulations 20I2. Singaporean governmental statute, created 8 November 20I2, updated 2I April 202I. https://perma.cc/Y7YV-REXC [Last accessed 2I April 202I].

Parreñas, Rhacel Salazar. (200I). Servants of Globalization: Women, Migration, and Domestic Work. USA: Stanford University Press.

Teo, Joyce. (2020). 'Coronavirus: WHO praises Singapore's containment of COVID-I9 outbreak'. Straits Times, Io March. https://perma.cc/75JE -5KMW [Last accessed 2I April 202I].

The Star. (2020). 'Singapore's domestic workers face "hidden plight" due to COVID-I9', I 5 May. https://perma.cc/X7QU-87KS [Last accessed 2 I April $202 \mathrm{I}]$.

Tyner, James. (2012). Space, Place, and Violence: Violence and the Embodied Geographies of Race, Sex, and Gender. UK: Routledge.

Women's Aid. (2020). A Perfect Storm: The Impact of the Covid-I9 Pandemic on Domestic Abuse Survivors and the Services Supporting Them. UK: Women's Aid.

Yang, Wong. (2020). 'Coronavirus: More maids running away during circuit breaker, say advocacy groups'. Straits Times, I 8 May. https://perma.cc/K93 S -3MAT [Last accessed 2I April 202I].

Zhuo, Tee. (2020). 'Coronavirus: MOM will revoke work passes of migrant workers in large gatherings if they refuse to disperse'. Straits Times, 25 March. https://perma.cc/G6HJ-Z 5 EF [Last accessed 2I April 202I]. 